\title{
A Case of Charcotian grande hystérie: Observation by Julien Offray de La Mettrie in 1738
}

Olivier Walusinski

Brou, France

\section{Key Words}

Hysteria $\cdot$ Catalepsy · Offray de La Mettrie $\cdot$ Charcot

\begin{abstract}
Julien Offray de La Mettrie (1709-1751) is a French philosopher who owes his fame to his materialist ideas. He was also a provocative atheist who used his scathing pen to defend the first concept of a theory of mind. We offer here one of his little-known works, reporting on a case of grande hystérie, as Jean-Martin Charcot (1825-1893) and his student Paul Richer (1849-1933) would describe the condition 150 years later. After discussing how La Mettrie interpreted this observation, we will compare it to interpretations developed during the 19th century, in particular by the La Salpêtrière school.
\end{abstract}

Copyright $\odot 2012$ S. Karger AG, Base

In addition to the major thinkers of the 18th century, such as Voltaire (François Marie Arouet, 1694-1778) or Denis Diderot (1713-1784), there were other, less wellknown figures such as Julien Offray de La Mettrie (17091751) or Claude-Adrien Helvétius (1715-1771), who nonetheless helped accelerate the philosophical movement that would lead to the most radical social renewal, the French Revolution.

\section{KARGER \\ Fax +4161306 1234 E-Mail karger@karger.ch} www.karger.com

\section{The Philosopher}

At a time when science was just starting to free itself from metaphysics, La Mettrie prefigured some of the major physiological discoveries (fig. 1). Although he is known as a materialist philosopher, one often forgets that he was, first and foremost, a physician. Opposed to the dualism of René Descartes (1596-1650), he suggested that the 'soul' was a reflection of the body, about the body: 'I see only matter in the brain; only expanse, as has been proven, in the sensitive part: living, healthy, well organised, this viscera contains an active principle within the medullary substance that is at the origin of nerves; I observe that this feeling, thinking principle stirs, sleeps and expires with the body. What am I saying! The soul is the first to sleep, its fire goes out as the fibres of which it is apparently composed weaken and fall one atop the other. If everything can be explained by what anatomy and physiology reveal to me in the spine, what need do I have to forge an ideal being?' $[1,2]$. Boldly and caustically expressing atheistic beliefs in his writings, he braved calumny from his fellow physicians as well as the clergy's hatred, which forced him to flee first to Holland (Leiden, 1746) before he was able, through the intermediary of mathematician Pierre Moreau de Maupertuis (1698-1759), to take refuge in Berlin (1748) with Frederick the Great (1712-1786), his only real

Olivier Walusinski, MD

20 rue de Chartres

FR-28160 Brou (France)

Tel. +33 2374707 77, E-Mail walusinski@baillement.com 


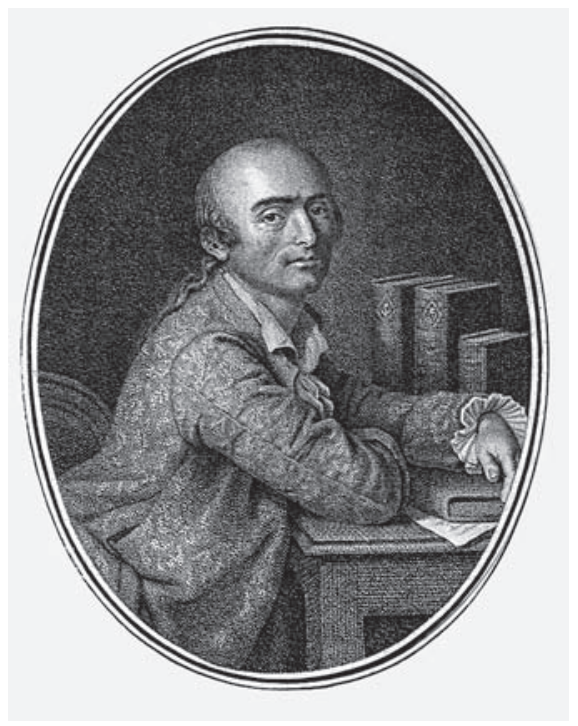

Fig. 1. Portrait of Julien Offray de La Mettrie, around 1770. Stipple engraving by Pierre-Guillaume Beljambe after Notté. Credit: Wellcome Library, London.

protector [3]. His exceptional verve and dialectical skill ensured his notoriety and sparked envy after the publication of his philosophical writings, which were also controversial, mocking and libertine, e.g. L'histoire naturelle de l'âme (1745), L'école de la volupté (1746), L'homme machine (1748) and L'art de jouir (1750) [6].

\section{Medical Writings}

La Mettrie's first medical work appeared in 1734, a translation of Aphrodisiacus by Herman Boerhaave (1668-1738), which had originally been published in Leiden (Netherlands) in 1728. Without informing the author, he added his own dissertation, Le système de $\mathrm{Mr}$ Herman Boerhaave, sur les maladies vénériennes (The system of Mr. Herman Boerhaave, on venereal diseases), in which he presented his own theories. The medical profession took notice and university academics, represented by Jean Astruc (1684-1766), did not fail to criticise La Mettrie. La Mettrie would later make fun of Astruc by referring to him as 'Savantasse', a pejorative term mocking his supposed learnedness. The dispute between the two men on the cause and treatment of syphilis would last several years and took the form of a series of opposing books. In 1737, La Mettrie presented his first original work, Traitédu vertige, avec la description d'une catalepsie hystérique (Treatise on vertigo, with the description of a case of hysterical catalepsy). It was a translation of his thesis written in Latin and defended in Reims in 1733. The work was published in Rennes by Veuve de P.A. Garnier (printer-bookseller, place du Palais).

After a brief biography of La Mettrie, we will present in its entirety, this little-known observation, not cited in any of the works written about hysteria in the 19th century. Curiously, it was transcribed by Paul Richer (18491933) in his thesis, which borrowed from the thesis of Alexis Favrot (1844), who had found it in an 1820 edition of the complete works of Samuel Tissot (1728-1797), compiled by Jean-Noël Hallé (1754-1822). Richer therefore attributed the text to Tissot, rather than La Mettrie, in addition to shortening it [7-9]. This is perfectly in keeping with La Mettrie's status as a proscribed thinker, a perception which persisted from his death until the middle of the 20th century. We shall nonetheless show that Jean-Martin Charcot could very well have written such an observation and similar commentary, which illustrates the originality of La Mettrie's medical thinking in the 18th century [10].

\section{A Short, Intense Life}

Julien Offray de La Mettrie was born in Saint Malo, Brittany, on 19 December 1709, in a family of wealthy merchants, as the reign of Louis XIV (1638-1715) was nearing its end. After studying rhetoric in Caen, La Mettrie went to Paris and became very interested in Jansenist doctrines. In parallel, he studied physics at the Collège d'Harcourt, which would later become Lycée Saint-Louis. Having completed his studies, he returned to Brittany where his father intended for him to enter the priesthood. But a physician from Saint Malo and friend of the family, François-Joseph Hunauld (1701-1742), who was also a professor of anatomy at the Jardin du Roy, encouraged La Mettrie to study medicine. Dissatisfied with the positions adopted by the Parisian academic establishment, he fled to Reims where he was able to defend his thesis more rapidly and less expensively, on 2 March 1733 . As a student, La Mettrie had only been interested in anatomy and dissection, and realising that his theoretical, archaic education had not adequately equipped him to practice medicine, he left in 1735 for the Dutch city of Leiden, which at that time was reputed to have the best medical schools in Europe. He took a passionate interest in the iatromechanical theories developed by his Dutch teacher, writing: 'Boerhaave was to medicine what Descartes was to phi- 
losophy' (Abrégé des systèmes). In 1738, he published Aphorismes de monsieur Herman Boerhaave sur la connoissance et la cure des maladies (Aphorisms of Herman Boerhaave on understanding and treating diseases), in 1739 Institutions de médecine de Mr Herman Boerhaave, in 1740 Traité de la petite vérole, avec la manière de la guérir, suivant les principes de Mr Herman Boerhaave, and ceux des plus habiles médecins de notre tems (Treatise on smallpox, including methods for curing it, according to the principles of Mr Herman Boerhaave and the most skilful physicians of our time), in 1741 Abrégé de la théorie chimique, tiré des propos écrits de Mr Herman Boerhaave (Summary of chemical theory, based on the writings of Mr Herman Boerhaave) and in 1743 Observations de médecine pratique [5]. Following the death of Hunauld, he returned to Paris and joined the French Guard as a physician under Louis XV. He participated in the Battle of Dettingen (27 June 1743) and in the victory at the Battle of Fontenoy (11 May 1745). But it was at the siege of Freiburg on 6 November 1744 that La Mettrie had a personal experience that profoundly changed his philosophy concerning the mind. Suffering from a high fever with episodes of delirium, he observed the course of his own illness and noted his findings on a day-to-day basis. $\mathrm{He}$ concluded that thought and mind are an expression of the brain function, the subject of a book he would publish in 1748, entitled L'homme machine (Man as machine). In delivering La Mettrie's eulogy on 20 January 1752, Frederick the Great stated: '... for the philosopher, an illness is a physics lesson; based on his observations, [La Mettrie] believed that thinking was merely a result of the machine's organisation and that a disturbance of its workings had a considerable influence on this part of ourselves which the metaphysicists call the soul. Suffused with these ideas during his convalescence, he dared to illuminate the dark recesses of metaphysics by holding up the light of experience; drawing upon anatomy in his attempt to explain the subtle texture of intelligence, he found only mechanics where others had assumed there to be an essence superior to matter. He published his philosophical conjectures in a work entitled Histoire naturelle de l'âme (Natural history of the soul) (1745)'. La Mettrie wrote: 'The soul is but a vain term for which there is no corresponding idea. An intelligent man should only use this term to refer to the thinking part of ourselves. And how can one conceive of matter's ability to think? I admit that I cannot conceive of this'. Perfectly aware of the outrage his book might provoke, although published in Paris, he had the following printed on the cover page, which did not mention the author's name: 'Translation from the

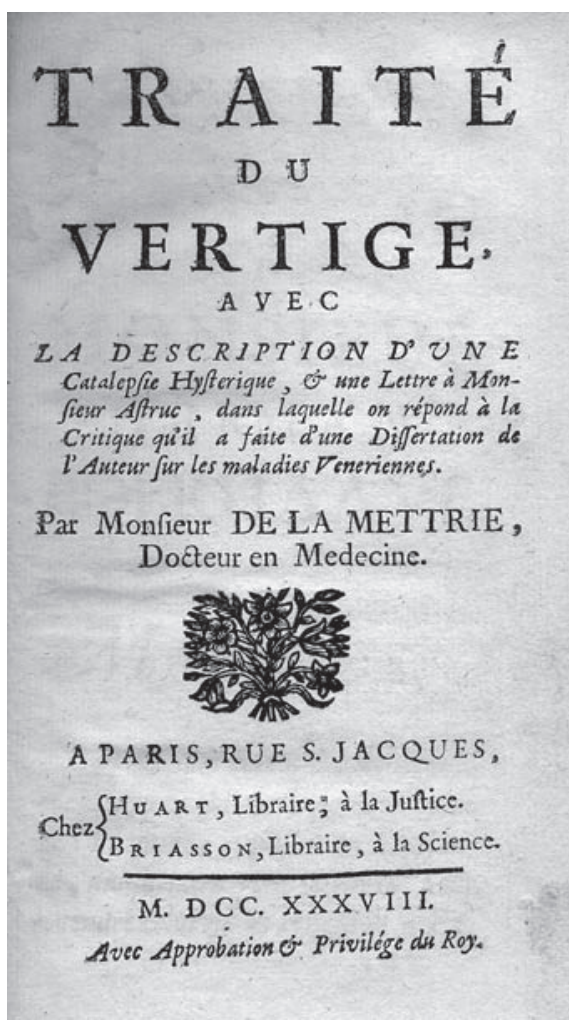

Fig. 2. Cover of the thesis by de La Mettrie 1738. Credit: Private collection of the author.

English of Charp by the late H..., La Haye, Neaulme, 1745'. La Mettrie died in Berlin at the young age of 43, leaving behind his wife and 5-year old daughter. Frederick the Great would say: '... it seems the affection knew her victim well, deftly attacking his brain first to strike him down without fail; he contracted a hot fever with violent delirium, being thereby obligated to call upon the science of his colleagues, and not finding the resources he had so often found, for himself and others, in his own science' $[1,5,12]$.

Below is a translation from the modern French version of the observation published in 1738 , at the end of the Traité du vertige (fig. 2).

\section{Description of a Case of Hysterical Catalepsy}

'Hélène Renault, residing in Saint Malo and aged 17 years, and Olive, her elder sister, were attacked, on the 11th and 15th of last March respectively, with an hysterical affection caused by the cessation of their menses. The 
elder sister only had five or six consecutive attacks and was soon radically cured, owing to the Emmenagogues and Anti-Hysterics I prescribed for her and which re-established her menses; the younger girl was not so fortunate, as the remedies that cured her sister only irritated her affection. After 10 or 12 attacks that were only Hysterical in nature, she fell into a true and perfect catalepsy, presenting symptoms of vapours. This represents a new metamorphosis not described by any author I know of.

Her fingers, phalanges, wrists, lower and upper arms, eyes and head all would remain immobile, in the position in which one placed her; this spectacle was so frightening that her mother had a violent attack of hysteria the first time she saw her daughter in this state. In addition to these occurrences common to cataleptics, her sense of smell was exquisite: if any slightly strong spirituous odour was brought within one or two inches of her right nostril, she would throw herself to the left; if one approached the other nostril, she would forcefully turn away to the right; if one removed the hand with which she clutched her nose, she would raise the other at an incredible speed; if one removed that hand, then the initially raised hand, which had remained suspended, would suddenly seem poised to defend all the more promptly this organ, sworn enemy of all sorts of strong odours, mainly sal volatile which she could smell at a distance of more than ten feet from her bed.

If the spirits were brought a little closer to her, she covered her face with a sheet or hid under the blanket, acting on an unknown instinct or perception that served her without the consent of her will. One had only to pronounce the name of these spirits and she would immediately be on her guard, like these madmen who need only hear certain words to enter their madness. Finally, if one dipped a feather in these spirits and brushed it against her nose to bring her back to her senses, she would scream horribly and deafly, shaking with violent convulsions, with fits of anger and rage; three men could not hold her still, even though prior to the attack, she had barely had the strength to speak. This obviously proves that while volatile spirits usually dispel catalepsy, they are always harmful in nerve diseases by the strong irritation they cause, and consequently when a physician has to treat a case of hysterical catalepsy like this one, he must not use spirits as violent to dispel the paroxysm. I noticed that smoke from a burning playing card had the same effect without any danger.

During the space of two months, the patient had more than twenty attacks of this catalepsy which I qualify as hysterical, given that it always followed hysteria: as the patient's oppression diminished, her eyes appeared more fixed, and when it ceased, the patient usually experienced a moment of scotodinia ('petit vertige ténébreux') causing her to fall softly on her pillow. Sometimes, however, the catalepsy was accompanied by uterine suffocation which was often followed by violent convulsions, and a delirium during which the patient exhibited far greater flights of fancy than in her healthy state. From time to time this young woman would dream during her cataleptic attack, seated on her bed, her body immobile, her head tilted, her eyes turning wherever one directed them, her arms bent and hanging, and then it would be quite pleasant to see her smile agreeably before speaking. She was like a supple statue capable of any kind of movement. After each attack, she had a period of apyrexia as in cases of intermittent fever, and she felt so well as to be convinced that she would never succumb to the disease again; however, the tiniest scare, a bit of bad news, the smallest cause of melancholy or anger, the slightest foul, hysterical odour, such as that of Castoreum or Rhuë, elicited an attack, and even accelerated its paroxysm.

After all these fits of hysterical catalepsy, the patient had a happy interval lasting nearly two months, which she owed to goat's milk, country air and, above all, exercise. But she had barely returned to the city when the catalepsy came back. Although it was no longer preceded by hysteria, there were other remarkable characteristics. It would always begin with the patient collapsing in weakness; sometimes syncope would also occur. At that point, if someone tried to prick her in order to bring her back to her senses, or expose her to some foul odour, she would become cataleptic, but usually in half her body only. She was also observed to fall into this more or less perfect demi-catalepsy independent of any outside cause. Finally this affection, which changed its form like a Proteus, took on a new aspect far more dangerous than those preceding it, becoming apoplexy. The first attack lasted three full days with convulsions of the lower jaw that were so violent that the teeth of this jaw could not be seen, and consequently she could take no food or water; since the month of August, she has had only two minor attacks of this cataleptic apoplexy.

The above is an account of Hélène Renault's affection; what I put forward is precisely true and has been seen by most physicians in Saint Malo. Those specifically interested in the various physical causes of catalepsy may consult Bellini, who in my opinion has explained them most clearly. Concerning the hysterical catalepsy observed in this case, I know of no other author who has described this condition. None of the accounts of catalepsy appear- 
ing after the dissertation of Dionis on sudden death resemble this one in any way, as can be confirmed. Several authors explain the causes and effects of hysteria, and when these are combined with Bellini's explanations of catalepsy, what is most marvellous about this account becomes apparent. Yet it is only marvellous for those unaware of the degree to which our machine can be disturbed; those enlightened by physics have a totally different way of thinking, persuaded that the movements of the human body that appear the most prodigious merely follow natural laws, although the most clever among these thinkers are without a doubt very far from a perfect understanding of these laws.

Instead of losing myself in vain arguments which would lead me astray, I shall simply note here what I have observed in the treatment of this type of affection.

(1) All remedies capable of re-establishing the patient's menses were used, to no avail.

(2) All the fetid antispasmodics recommended by all physicians in the treatment of vapours were always found to be very harmful.

(3) Around fifteen or sixteen pounds of blood were drawn over the course of the affection, from the arms, feet, neck and nose.

(4) All aqueous remedies had salutary effects.

(5) Narcotic succinum syrup often immediately calmed the patient's nervous erethism and mental ataxia.

(6) For the two months since her last attack, the patient has had a kind of diarrhoea maintained by light purgatives, which she credits with her cure; I do not doubt that this evacuation has played an important role, and one can infer that these purgatives, mainly Hydragogues, are suitable for this type of affection.

(7) A very moist environment was always created for the patient.

This is a brief description of the therapeutic method followed. The patient appears in perfect health, although her menses have not yet returned. For this reason, all means for re-establishing them are currently being used to bring about a radical cure.'

\section{Hysteria during La Mettrie's Time}

Since the end of the 17th century and in keeping with classical nosography, a wide variety of somatic manifestations have been associated with hysteria. This condition was seen as having a particular progression, which often fooled the physician by a fluctuating variety of symptoms [13]. Since William Harvey's description of blood circula- tion in 1628 , it was no longer possible to speak of the flow of 'pneuma', a vital material in the arteries according to classical doctrines. 'Vapours', related to 'fermentation of humours' and believed to circulate in nerve interstices, replaced the classical theory for a century. However, vapours always originated in the 'womb' and could rise from the 'entrails to the brain'. Their effects depended on how they diffused through the organism. Lange, in his treatise on vapours (1689), explained: '... they (the seminal ferments) cause such swelling and so much elevation of the parts where the nerves are attached that the diaphragm is pressed, such that the uterine body is seemingly moved to this place like a large ball. If the vapours enter the nerves of the lungs, they result in convulsive asthma. When they are pushed into the nerves of the heart, they result in a convulsive pulse and palpitations. When they rise to the recurrent nerves, they produce strangulation and suffocation. Finally, when they rise to the brain, they provoke the same accidents that we explained for epilepsy' [14, 15]. Joseph Lieutaud (1703-1780), a physician and contemporary of La Mettrie, aptly described the theory commonly accepted at that time: 'Disturbances of uterine function lead even more directly to hysterical affections: delays in menstrual flow, its suppression or retention, its reduction, its anomalies, and its spontaneous, accidental, delayed or premature cessation' [16].

In keeping with these notions, La Mettrie attributed his patient's symptoms to her amenorrhea. For him, the older sister rapidly recovered through the return of her menstrual cycle. We should note that into the early 19th century, this theory of 'uterine neurosis' persisted and was still defended, in 1816, by Jean-Baptiste Louyer-Villermay (1775-1837) and in 1837 by Elionor-Frédéric Dubois d'Amiens (1797-1873) [17, 18]. In 1738, the same year he wrote the above observation, La Mettrie translated into French the aphorisms of his much admired teacher, Boerhaave (the book gives the translator as ${ }^{* * *}$ ) and enumerated the causes that trigger epilepsy: 'violent nervous affections, such as severe menstrual pains and hysterical passion; the suppression of evacuations such as saliva, puss, menses, diarrhoea, haemorrhoids, urine; the paroxysm is renewed by fumes which rise from their nidus to the brain like a vapour' [19]. We can thus understand La Mettrie's thinking, but it is nonetheless surprising that he was unaware that Nicolas Le Pois (1527-1590, from the region of Lorrain), in 1585 [20], according to Louis Lepec de La Cloture (1736-1804) [21], 'viewed this affection as an idiopathic brain disease, in no way different from epilepsy, and common to both sexes'. Equally 
surprising, La Mettrie was unaware that in England, Thomas Willis (1621-1675) in 1667, and Thomas Sydenham (1624-1689) in 1684, had also defended the hypothesis that hysteria originated in the brain $[22,23]$. Even more surprising, the commentaries of Gerard Van Swieten $(1700-1772)$ on the aphorisms of Boerhaave, which Van Swieten published in 1745, describe hysteria as a disease common to both sexes and state that the origin of 'the hysterical affection was in the nerves that are distributed to the viscera in the lower belly, which explains that the disturbance is transmitted to the brain, thereby producing convulsions'. Although these commentaries were published after La Mettrie's observation, it is likely that his teacher in Leiden had personally presented him with these ideas $[24,25]$.

\section{J.M. Charcot (1825-1893) and Sensory Excitation during Catalepsy}

La Mettrie's description of catalepsy is aligned with that given by Friedrich Hoffmann (1669-1742), and with Lieutaud's description during his time: 'Another type of general convulsion has been referred to, which is called catalepsy and which has been the subject of many fables. It is merely a degree of the other convulsions, in which the more flexible parts can move and retain the position given to them. Catalepsy is mainly seen in the hypochondriacal and hysterical affection, and requires the same treatment' $[16,26]$. While his description is succinct, it emphasises the importance of perceptual changes during this state, an idea which was developed by Timothée Puel (1812-1890) and Claude-Etienne Bourdin [27, 28]. A little later, a student of Charcot, Georges Guinon (1859-1932) would publish, in 1891 with Sophie Wolkte of Odessa, in Nouvelle Iconographie de La Salpêtrière, three observations very similar to La Mettrie's, entitled 'De l'influence des excitations sensitives et sensorielles dans les phases cataleptique et somnambulique du grand hypnotisme' (On the influence of sensitive and sensory excitations in the cataleptic and somnambulic phases of grand hypnotisme). The first observation concerns 'Blanche' Marie Wittmann, the famous hysteric immortalised in the arms of Joseph Babinski (1857-1932) at Charcot's side in the painting of André Brouillet (1857-1914), 'Une leçon clinique à La Salpêtrière' [29].

Below is an extract of what Guinon reported: 'By lifting the eyelids, we produced catalepsy, and after verifying that this phase legitimately presented the distinctive characteristics, we placed a red glass plate in front of the patient's eyes. We immediately saw her smile slightly and her face take on an expression of pleasure and joy. There was no movement in her limbs.

Blue Glass Plate. She wrinkled her brow and her physiognomy showed sadness...

Yellow Glass Plate. She showed every sign of being very frightened.

Dark Green Glass Plate. Her physiognomy expressed surprise, then admiration. These two feelings were very clear. The patient lifted and spread her arms, as when one is struck by admirative surprise.

Placing a light green glass plate in front of the patient's eyes did not change the scene described above. After these excitations of the sense of sight, we turned to the sense of smell, placing an open vial of an odoriferous substance under the patient's nostrils.

Carbon Disulphide. The patient's face expressed profound disgust. Her right hand lifted and her head turned away as if to block out a horrible, repulsive sight.

Eau de Cologne. The scene changed subtly. The patient smiled and showed signs of great contentedness. She looked off into the distance. She raised her right hand, as if to initiate a gesture, which she did not complete, her hand in a half-way position. The patient remained frozen in the expression she had at that moment, as if the picture had disappeared and she had retained, as seen in catalepsy, the gesture and physiognomy related to what was suggested in that moment.

Chloroform. Intense disgust, repulsion. She jerked her head backwards violently. Then her face took on a sad expression. It seemed she was going to cry.

Camphorated Ether. Contentedness, slight smile (certain hysterics rather enjoy the inebriation of the ether administered to calm their attacks)'.

In his thesis defended in 1887, a student of Albert Pitres (1848-1928) in Bordeaux named Léopold Lichtwitz (1858-1943) expressed the opinion that 'the nasal mucous membrane may be, of all the mucous membranes, the least subject to anaesthesia'. On this subject, Georges Gilles de la Tourette (1857-1904) noted in his treatise: '... although M. Lichtwitz never found the nasal mucous membrane to be completely anesthetised, it could not be exempt from this general law, according to which, as Charcot teaches, the mucous membranes participate in the anaesthesia of the hemianaesthesised side, and the sensory disturbances are generally superimposed on the sensitive disturbances' [30, 31]. Already in 1859, Pierre Briquet (1796-1881) had noted: '... given that the lack of sensitivity most often affects one nostril, patients often do not perceive it; they merely say that they have lost their 


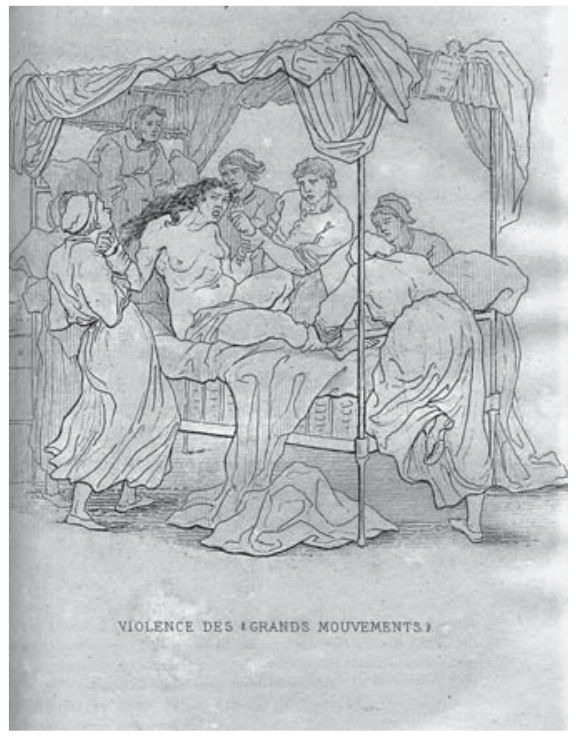

Fig. 3. Engraving by Paul Richer (1849-1933), illustrating his medical thesis: Etudes cliniques sur l'hystéro-épilepsie ou grande hystérie. Paris. A. Delahaye and E. Lecrosnier. 1881. Credit: Private collection of the author.

sense of smell' [32]. It is interesting to note that the cases described by La Mettrie and Guinon invalidate the observations of Briquet, Charcot and Gilles de la Tourette. It is perhaps Lichtwitz who best described these differences [30]!

\section{Demoniacal Attack}

La Mettrie's description of what caused the major attack - 'if one took a feather dipped in these spirits to brush against her nose' - could have been written by Paul Richer (1849-1933) for his treatise inspired by Charcot, Études cliniques sur l'hystéro-épilepsie ou grande hystérie (Clinical studies on hystero-epilepsy or grande hystérie) (fig. 3, 4). He wrote: 'In one of our patients, B... I observed on several occasions that a manifest cataleptic state inaugurated the grande hystérie (hystero-epilepsy). With her eyes wide open and staring at a point in space, she was motionless and her non-rigid members maintained the attitudes given them. After only a few instants, twitches were observed, at first spread out in time, then growing progressively more frequent. This was followed by tetany with epileptoid period' [9]. Richer described what Charcot called the 'demoniacal attack' which resembles La Mettrie's description in every aspect: 'She made large

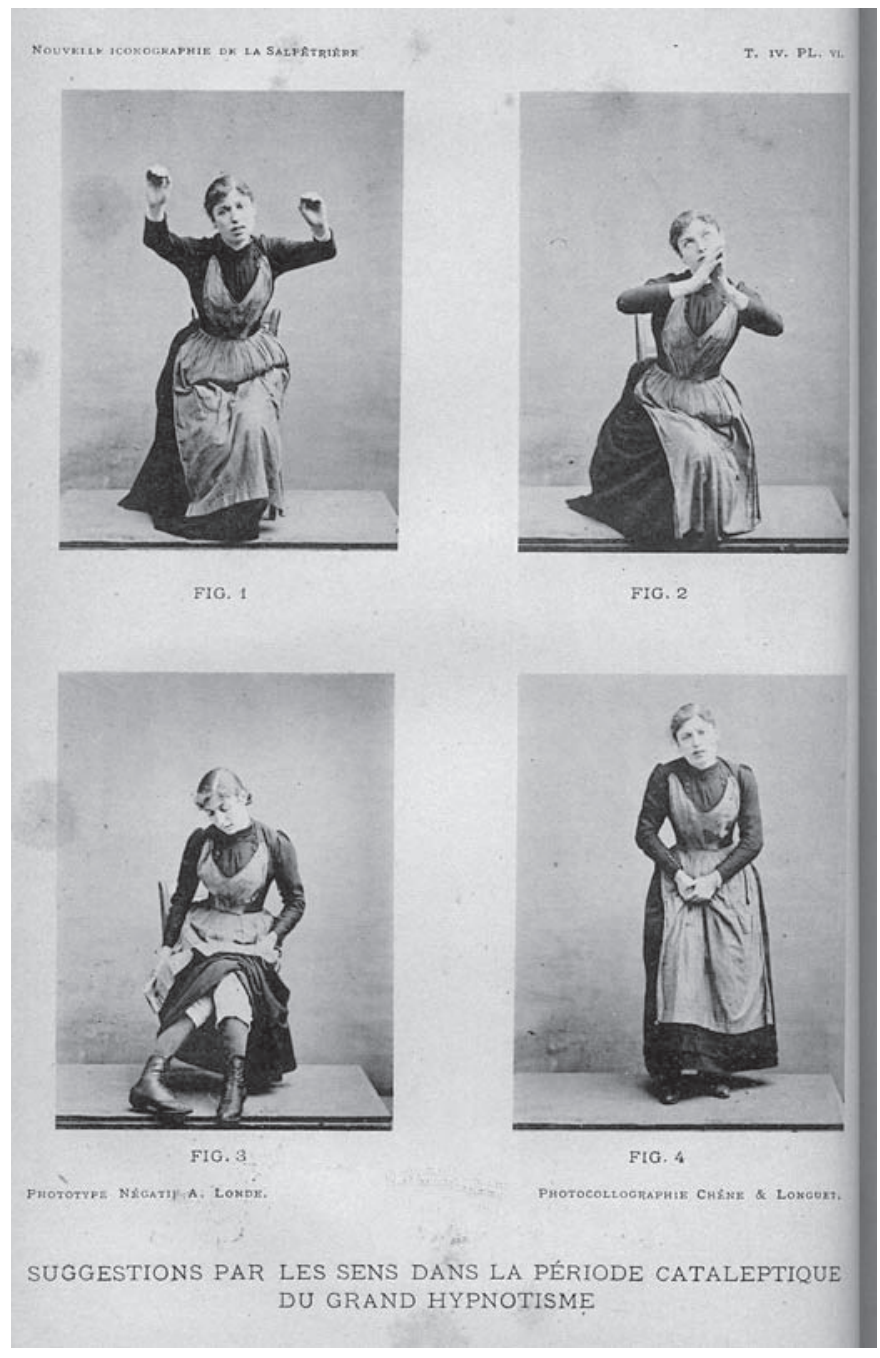

Fig. 4. Image illustrating George Guinon's paper in La nouvelle Iconographie de La Salpêtrière. Paris. Veuve Babé Libraire-éditeur. 1891. Credit: Private collection of the author.

movements with a frightening violence. The patient tried to bite herself and scratch her face and chest. She tore at her hair, hit herself violently, cried out in pain and yelled like a ferocious beast'. Richer noted that during the following period, 'the emotional attitudes did not exist, strictly speaking. Hallucination could occur, but the contraction which often persisted hindered the patient's movements. She could be seen to smile, call on an imaginary being or make a face at this being' [9]. La Mettrie's patient presented this clinical picture: 'her arms bent and hanging, [she would] smile agreeably before speaking [...] like a supple statue capable of any kind of movement'. It is more difficult to understand what La Mettrie describes 
as apoplexy, since he seems to refer more to a convulsive state than to paralysis. Similar descriptions but without catalepsy can be found in the rather confused thesis of Charles Achard (1860-1944), defended in 1887 [33].

\section{The Explanations Given by La Mettrie}

La Mettrie leaves us with the task of finding an explanation of catalepsy in the works of the Italian author Lorenzo Bellini (1643-1704), who taught medicine and anatomy at the University of Pisa for thirty years. He is better known for his dissertation on tubes in the kidney known as the duct of Bellini than for his neurological descriptions [34]! We were unable to identify the work to which La Mettrie refers. The surgeon Pierre Dionis (16431718) transcribed a thesis defended in Montpellier in 1713 , in which catalepsy is defined as 'an abolition of animal functions, in which the patient's limbs remain immobile, and in the same position in which the patient was attacked, but they keep the attitude given them, if someone places the patient in various postures'. He considered catalepsy a brain pathology close to apoplexy or epilepsy. His observation resembles that of La Mettrie but Dionis never once mentions the word hysteria: '[...] the lesions to which cataleptics are subject sufficiently prove that in every type of catalepsy the lower part of the brain is attacked, because the soul through its association with the body, can only exercise its functions through the proper vibrations of the brain fibres' [35].

Thus, except for Richer who referred to La Mettrie's observation without realising it, none of the authors of treatises on hysteria, an important theme in 19th century medicine, cite La Mettrie - not Louyer-Villermay, JeanLouis Brachet (1789-1858), Alexandre Brierre de Boismont (1798-1881), Hector Landouzy (1812-1864), Briquet, Charcot nor Gilles de la Tourette, nor any of the other students of Jean-Martin Charcot [36-38]. Similarly, the student of Pierre Cabanis (1757-1808), Hippolyte Cloquet (1787-1840), only describes lesional organic pathologies in his innovative work on the sense of smell, or osphresiology, making no mention of the hysterical disturbances of smell like those that La Mettrie recounts [39].

La Mettrie was a forerunner of positivism and possessed a remarkably perspicacious intellect. The materialism he proposed was not merely mechanistic. His ideas reveal the beginnings of a theory of mind, a system of emotions and how stress acts on the organism, an evolutionist theory and finally, a universal eroticism. His conception of the world can be seen to evolve between his first and last works. Nature, initially conceived of as a creative power, becomes subject to chance. His premature death deprived us of the elaboration he could have given these concepts, which blossomed in the 20th century and continue to do so today. They are the very reason we should take another look at Julien Offray de La Mettrie [40].

\section{References}

1 Offray de La Mettrie J: (Hunauld FJ: auteur supposé). Histoire naturelle de l'âme, traduite de l'anglois de M. Charp, par M. $\mathrm{H}^{* *}$ de l'Académie des sciences. A La Haye. Chez Jean Neaulme, libraire, 1745, p 398.

2 Maitre J-M: Un médecin philosophe: de La Mettrie (1709-1751). Thèse Paris No 90. Paris, Imprimerie Jouve, 1919, p 65.

3 Quépat N: La philosophie matérialiste au $\mathrm{XVIII}^{\circ}$ siècle: Essai sur La Mettrie, sa vie et ses oeuvres. Paris, Librairie des Bibliophiles, 1873, p 206

4 Damiron JC: Mémoire sur de La Mettrie. (Extrait du Moniteur Universel.) Paris, Imprimerie Panckoucke, 1850, p 98.

$\checkmark 5$ Soddard RE: Julien Offray de La Mettrie, 1709-1751: a bibliographical inventory. The Papers of the Bibliographical Society of America 1992;86:411-459.

6 Wolfe C: La réduction médicale de la morale chez La Mettrie; in Audibière S, Bourdin JC, et al. (eds): Matérialistes français du XVIII ${ }^{\circ}$ siècle. Paris, PUF, 2006, p 366.
7 Favrot A: De la catalepsie, de l'extase et de l'hystérie. Paris, Imprimerie Rignoux, 1844, p 110.

8 Tissot S: Euvres complètes de Tissot. Nouvelle édition, précédée d'un Précis historique sur la vie de l'auteur et accompagnée de notes par JN Hallé. Paris, Allut, 1820.

9 Richer P: Études cliniques sur l'hystéro-épilepsie ou grande hystérie. Paris. A. Delahaye and E. Lecrosnier, 1881, p 736.

10 Brazier M: A history of neurophysiology in the 17th and 18th centuries. New York, 1984, p 230.

11 Ochs S: A history of nerve functions: from animal spirits to molecular mechanisms. New York, Cambridge University Press, 2003, p 438.

12 Frédéric II: Roi de Prusse. Éloge de M. Julien Offroy de La Mettrie. Berlin, 1752, p 20.

13 Trillat E: Histoire de l'hystérie. Paris, Seghers, 1986, p 282.

14 Lange M: Traité des vapeurs où leur origine, leurs effets, et leurs remèdes sont méca- niquement expliqués. Paris, Chez la Veuve de Denis Nion, 1689, p 295.

15 Whitaker H, Smith CUM, Finger S: Brain, mind and medicine: essays in eighteenthcentury neuroscience. New York, Springer, 2007, p 376.

16 Lieutaud J: Précis de la médecine pratique, contenant l'histoire des maladies et la manière de les traiter, avec des observations et remarques critiques sur les points les plus intéressans. Paris, Chez Vincent, 1765, p 610.

17 Louyer Villermay JB: Traité des maladies nerveuses ou vapeurs et particulièrement de l'hystérie et de l'hypochondrie. Paris, Chez Méquignon, 1816, vol 2, p 787.

18 Dubois d'Amiens EF: Histoire philosophique de l'hypochondrie et de l'hystérie. Paris, Chez JB, Baillière, 1837, p 551.

19 Offray de La Mettrie J: Aphorismes de Monsieur Boerhaave sur la connoissance et la cure des maladies. Rennes, Chez veuve Garnier, 1738, p 508. (Deuxième tirage, Paris, Chez Pierre-Michel Huart, 1738, p 508.) 
20 Le Pois N: De cognoscendis et curandis praecipue internis humani corporis morbis libri tres. Francofurd, Apud Haaeredes Andreae Wechelii, 1585, p 968.

21 Lepecq de La Cloture A: Dissertation sur l'hystérie. Thèse, Paris, Didot le Jeune, 1831, p 52.

22 Willis Th: Pathologiae cerebri et nervosi genris specimen; in quo agitur de morbis convulsivus, et de scorbuto. Oxford, Allestry, 1667, p 123.

23 Sydenham T: Dissertatio epistolaris: ad spectatissimum Doctissimumque virum Gulielmum Cole, M.D. de observationibus nuperis circa curationem variolarum confluentium, nec non de affectione hysterica. Genevae, Apud Samulem de Tournes, 1684, p 141.

24 Boerhaave $\mathrm{H}$ : Aphorismi de cognoscendis et curandis morbis. Lugduni Batavorum, Vander Linden, 1715, p 344.

25 Van Swieten G: Commentaria in Hermanni Boerhaave aphorismos de cognoscendis et curandis morbis. Lugduni Batavorum. Apud Johannem et Hermannum Verbeek, 1745, p 685.

26 Hoffmann F: Opera omnia physico medica. Genève, Fratres de Tournes, 1740, tome 3, p 355.
27 Puel T: De la catalepsie. Paris, J.B. Baillière, $1856, \mathrm{p} 118$

28 Bourdin CE: Traité de la catalepsie. Paris, J. Rouvier, 1841, p 216.

29 Guinon G, Wolkte S: De l'influence des excitations sensitives et sensorielles dans les phases cataleptiques et somnambulique du grand hypnotisme. Nouvelle Iconographie de La Salpêtrière. Paris, Veuve Babé, 1891, vol 4, pp 77-88. [Reparu dans Charcot JM: Leçons mémoires notes et observations parus pendant les années $1889-1890$ et 1890 1891 et publiées sous la direction de G. Guinon. Paris, Le Progrès Médical, 1893, p 482.]

30 Lichtwitz L: Recherche clinique sur l'anesthésie des muqueuses et de quelques organes des sens (goût, odorat, ouï) et sur les zones hystérogènes des muqueuses. Thèse 28/03/1887. No 40. Bordeaux, Imp Nouvelle A. Bellier, p 184.

31 Gilles de la Tourette G: Traité clinique et thérapeutique de l'hystérie d'après l'enseignement de La Salpêtrière. Paris, Plon, Nourrit et Cie, 1891-1895, vol 3, p 1745.

32 Briquet $P$ : Traité clinique et thérapeutique de l'hystérie. Paris, J.B. Baillière et fils, 1859, p 724 .
33 Achard Ch: De l'apoplexie hystérique. Paris, Asselin and Houzeau, 1887, p 99.

34 Bellini L: De urinis et pulsibus, de missione sanguinis, de febribus, morbis capitis, et pectoris. Francofurti and Lipsiae, Christiani Scholvini, 1685, p 688.

35 Dionis P: Dissertation sur la mort subite. Avec l'histoire d'une fille cataleptique. Paris, Laurent d'Houry, 1710, p 189.

36 Brachet JL: Traité de l'hystérie. Lyon, Ch Savy Jeune, 1847, p 514.

37 Brierre de Boismont A: Des Hallucinations, ou Histoire raisonnée des apparitions, des visions, des songes, de l'extase, du magnétisme et du somnambulisme. Paris, Germer Baillière, 1862, p 720.

38 Landouzy H: Traité complet de l'hystérie. Paris, Germer Baillière, 1846, p 420.

39 Cloquet H: Osphrésiologie ou Traité des odeurs, du sens et des organes de l'olfaction, avec l'histoire détaillée des maladies du nez et des fosses nasales et des opérations qui leur conviennent. Paris, Méquignon-Marvis, 1821, p 758.

40 Pénisson P: La Mettrie à Berlin; in Audibière S, Bourdin JC, et al. (eds): Matérialistes français du XVIII ${ }^{\circ}$ siècle. Paris, PUF, 2006, p 366 